\title{
Etiologies of Arthritis in Sub-Saharan Africa Rheumatology Practice
}

\author{
N. E. Lamini N'Soundhat, A. P. Salémo, D. C. Nkouala-Kidédé, \\ F. E. Omboumahou Bakalé, H. Ntsiba \\ Rheumatology Department of Brazzaville University Teaching Hospital, Congo \\ Email: nlamini@yahoo.fr
}

Received 25 June 2016; accepted 3 August 2016; published 5 August 2016

Copyright (C) 2016 by authors and Scientific Research Publishing Inc.

This work is licensed under the Creative Commons Attribution International License (CC BY).

http://creativecommons.org/licenses/by/4.0/

(c) (i) Open Access

\begin{abstract}
Objective: To research distribution of etiologies modification of arthritis in Congo-Brazzaville, twenty years after the first reports. Methods: A cross sectional study has been achieved. Medical files of patients admitted for arthritis between 2000 and 2014, in Rheumatology department of Brazzaville university teaching hospital have been included. Among 416 patients listed as cases of arthritis, 201 answered to the inclusion criterias have been kept for analysis. The etiological diagnoses were based on criterias of classification and/or diagnosis used in Rheumatology. Results: 201 patients, 110 men $(54.72 \%)$ and 91 women $(45.28 \%)$ were included. The sex-ratio was 1.2 , and average age was 45.5 years old (extremes: 8 - 86 years). Among them, 72 patients had microcrystal arthritis. Septic arthritis and those associated with HIV constituted the second etiological group of 60 patients and respectively, 32 were bacterial and $28 \mathrm{HIV}$ associated arthritis. 58 remaining patients had a chronic inflammatory arthritis. Etiology distribution showed that gout was the most frequent (33.83\%), followed by septic arthritis $(15.92 \%)$, HIV associated arthritis (13.93\%) and rheumatoid arthritis (11.94\%). In 11 patients (5.5\%), etiology was unknown. Conclusion: Three decades after the first publications in Brazzaville, the etiologies of arthritis remain dominated in order of frequency by gout, septic arthritis and HIV associated arthritis and rheumatoid arthritis. The frequency of indeterminate arthritis decreased significantly. Spondy-loarthropathy and autoimmune diseases are more common diagnosis.
\end{abstract}

\section{Keywords}

Arthritis, Gout, Septic Arthritis, HIV Associated Arthritis

\section{Introduction}

The etiologies of arthritis in sub-Saharan Africa are better reported since three decades [1]-[3]. The first reports

How to cite this paper: Lamini N'Soundhat, N.E., Salémo, A.P., Nkouala-Kidédé, D.C., Omboumahou Bakalé, F.E. and Ntsiba, H. (2016) Etiologies of Arthritis in Sub-Saharan Africa Rheumatology Practice. Open Journal of Rheumatology and Autoimmune Diseases, 6, 57-62. http://dx.doi.org/10.4236/ojra.2016.63010 
corresponded to the creation of clinical units, managed by African rheumatologists. These publications highlighted septic arthritis invalidated the rarity of gout in black Africans and revealed existence of human immunodeficiency virus (HIV) associated arthritis [4]-[7]. However in 30\% of cases, no etiology was identified. The training of more numerous African rheumatologists, creation of rheumatology departments and disposing an improved technical tray (computed tomography scan, magnetic resonance imaging, blood-immunological evaluation) have modified the panorama of arthritis in sub-Saharan Africa. Are the cases of unknown arthritis etiology have been reduced? In Brazzaville (Congo) in 1994, three etiologies of arthritis predominated in a report set of 473 cases, covering a period of six years. It was about septic arthritis, HIV associated arthritis and gout. Rheumatoid arthritis was the most frequent chronic inflammatory rheumatism. The lupus, reactive arthritis and spondyloarthropathies seemed rarer. Twenty years after, it appeared opportune to us, in the same methodological conditions and the same environment of practice, to determine the etiologies of rheumatic arthritis in order to measure their frequency, identify possible modifications of frequency and to determine the part of indeterminate arthritis.

\section{Patients and Methods}

It's a retrospective study conducted on 2014, in Rheumatology Department of Brazzaville university teaching hospital. It consisted in a review of patients admitted in hospitalization or seen in consultation, from January 2000 to June 2014. The files having a quotation indicating “arthritis” were recruited, corresponding for the target population. The inclusion and exclusion criterias permitted selection of exploitable files representing the survey population. Were included the files for which the observation contains a clinical description of arthritis and inflammatory biologic signs. Other files without these items were excluded to the survey. The analysis of every file was based on criterias of classification and/or usual diagnosis in rheumatology [8]. However for septic arthritis, in the absence of germ isolation, diagnosis was kept on the basis of anamnesis, clinic and biologic arguments and strong presumption imagery (intervening sharp brutal, predisposed context, entry door, thrills, systemic inflammatory syndrome, erosions and pinch). For HIV associated arthritis, the diagnosis was kept on a HIV + patient, presenting arthritis for which no other etiology was recovered and that especially, the acquired immunodeficiency syndrome (AIDS) was diagnosed and was classified. During the period of survey, 11,229 patients have been exanimate in our rheumatology department. The recruiting criterias (codification of arthritis) permitted to list 416 cases of arthritis. The criterias of inclusion and exclusion permitted to select 201 exploitable files. Confidentiality and anonymous of patients were observed.

\section{Results}

Two hundred and one (201) patients, 110 men (54.72\%) and 91 women (45.27\% were selected. Sex-ratio was 1.2 with average age of 45.5 years old and extremes from 8 to 86 years. The criterias of diagnosis and classification permitted to identify five groups (Figure 1 and Figure 2): microcrystal arthritis 72 cases (35.82\%); chronic inflammatory rheumatisms 58 patients (28.85\%); septic arthritis 32 cases (15.92\%); HIV associated arthritis 28 patients (13.93\%); indeterminate arthritis 11 cases (5.47\%). Gout observed in 68 cases (33.83\%), constituted the first etiology of arthritis. It concerned 64 men (94\%) and 4 women (6\%), developing as an acute crisis in 16 patients and as chronic in 52 cases. For these, 23 patients had a narrow joint, 13 a tophus and 11 a renal failure. Gouty arthritis was polyarticular in $75 \%$ of cases. The chondrocalcinosis was recovered in 4 cases, (1.99\%). The second etiology was represented by septic arthritis observed in 32 patients (15.92\%). It was monoarticular in 27 cases and oligoarticular in 5 cases. The predilection location was the knee in 22 cases, followed by the hip 7 cases, ankle 4 cases and shoulder in 2 cases. Joint fluid analysis in 15 cases is permitted to identify staphylococcus aureus in 6 cases and streptococcus in 2 cases. In 7 cases none germ could not be isolated. The entry door recovered in 18 cases, was cutaneous in 9 cases, dental in 3 cases and respectively twice in pulmonary, digestive and urinary. In 1 case the infection followed a knee surgical act. The HIV associated arthritis, seen in 28 cases (13.93\%), constituted the third etiology. They occurred among the patients seen to the B stage in 10 cases; C stage in 17 cases of the CDC/AIDS classification. Only one patient was at the A stage. They presented an acute and none erosive polyarticular synovitis, none distorting in 25 cases (89.3\%), oligoarticular in 2 cases (7.2\%) and monoarticular in 1 case (3.6\%). In any case, the criterias of spondyloarthropathy were not united. The evolution was regressive under no steroid anti-inflammatory drugs during 4 to 6 weeks. Rheumatoid arthritis with 


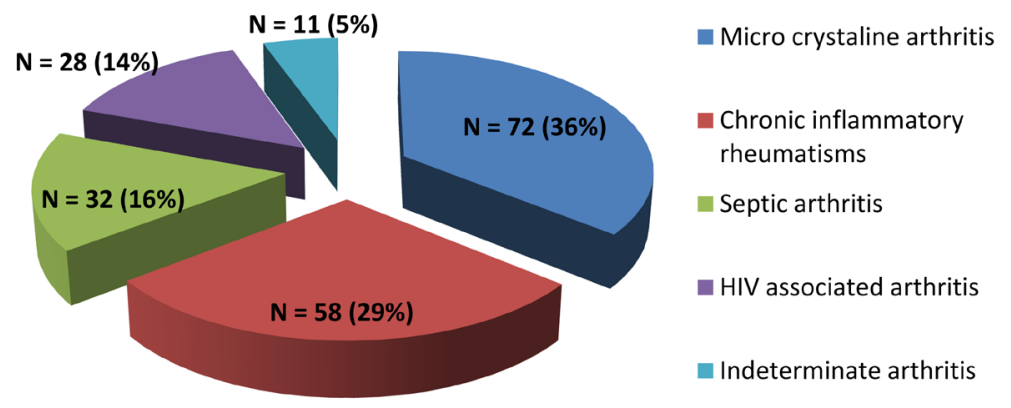

Figure 1. Breakdown group of arthritis.

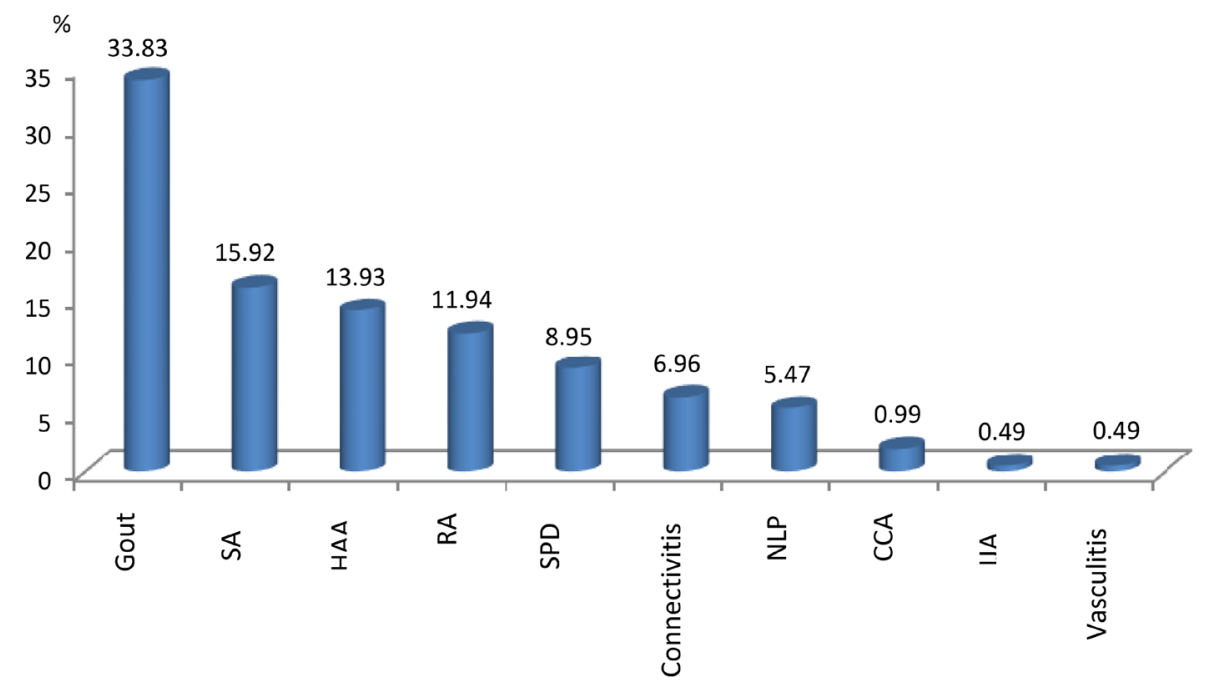

Figure 2. Main etiologies of arthritis. Legend: SA (septic arthritis); HAA (HIV associated arthritis); RA (rheumatoid arthritis); SPD (spondyloarthropathy); NLP (non labeled polyarthritis); CCA (chondrocalcinosis); IJA (idiopathic juvenile arthritis).

24 cases (11.94\%) was the fourth etiology of arthritis. It is the most frequent chronic inflammatory rheumatism, predominant on women (23 cases). The bilateral, symmetrical, distorting arthritis and distal predominance were the following presentation. Extra joint location was noted in 7 cases, as subcutaneous nodosity, GougerotSjögren syndrome and Raynaud syndrome in 2 cases respectively and pericarditis in 1 case. The spondyloarthropathies with 18 cases (8.95\%) were the fifth etiology. The preferentially axial attack in 14 cases was associated to arthritis in 11 cases, oligoarthritis in 4 cases, monoarthritis in 3 cases and a peripheral enthesopathy in 4 cases. No case responds to ankylosing spondylitis criteria. Extra joint expression was a diarrhea in 7 cases, uveitis in 2 cases, conjunctivitis, uretritis and psoriasis in 1 case respectively. Systemic erythematous lupus with 8 cases (3.98\%) all feminine sex, was the sixth etiology of arthritis. The mixed connectivitis diagnosis had been kept in 6 cases. In other respects, on the basis of clinical arguments, it has been diagnosed 1 case of juvenile chronic arthritis and another case of vasculitis. Unknown arthritis seen in 11 cases (5.47\%), mainly had bilateral, asymmetric arthritis of the big joints, non erosive, evolving on an acute or sub acute mode or, sometimes interrupted by recurrences, serological and immunological biologic exams were not contributive for a specific etiology.

\section{Discussion}

This work treats the hospitable frequency of arthritis in sub-saharan Africa practice. It is added to the previous studies led in the same methodological conditions, mainly in Brazzaville (Congo) [9], in Yaoundé (Cameroon) [1] and in Lomé (Togo) [10]. In doing so, it allows them to assess trends in three decades.

The main observation is the reduction of cases number of indeterminate arthritis. These varied from $21.82 \%$ 
in Brazzaville [3] to 36.91\% in Lomé [10] within the arthritis all disconcerted etiologies. These unknown arthritis etiologies represented 37.14\% of cases of chronic arthritis in Lomé [11] and 17.5\% of oligoarthritis in Brazzaville [12]. They were imputed then to the numerous notably parasitic infectious solicitations, whose witness was the constancy of a polyclonal gammapathy. The training of African rheumatologists, the opening of rheumatology specialized units and improvement of biologic investigating capacities, contributed plausibly to have the diagnosis of arthritis with more certainty, reducing thus part of indeterminate etiologies.

In good number of cases, these undifferentiated arthritis, in their initial presentation, adopt during their evolution, a shape differentiated like spondyloarthropathy or rheumatoid arthritis [13]. The presentation like exsudative synovitis of weak abundance and their clinical features would invoke a spondyloarthropathy. However, the absence of enthesopathy and extra joint signs doesn't permit to satisfy the criterias of classification of it. So the hypothesis reported by Biléckot and al remains actuality [12]. The melanoderm group, usually HLA B 27 negative, doesn't adopt a shape of enthesopathy in front of post infectious, psoriatic or enteritis solicitation.

The parasitic etiology could be refuted by absence of arthritis of this type to the children quite often affected by diseases caused by parasites. However, for systematic deworming mentioned in sub-saharan Africa, it can explain the occurrence reduction of parasitic arthritis.

The triad gout, bacterial arthritis, HIV associated arthritis is found two decades after, in the same order, confirming the analysis of 473 cases of arthritis achieved in 1994 by Biléckot and al [9].

The gout remains the first cause of arthritis in tropical Africa [6] [14] [15], equatorial [4] [10] and southern [16]. In sub-Saharan hospitable practice, the chronic polyarticular presentation is more frequent, essentially revealing a long delay of diagnosis or management [10] [15], joining So, Busso et al. preoccupation for the necessity of physicians and patients information and education [17].

In a continent where the infectious illnesses have in long time constituted the main priority of public health, banal germs septic arthritis and those due to tuberculosis are reputed frequent. Septic arthritis prove to be the second cause of arthritis in equatorial and tropical Africa [14] [18]-[20]. The clinical and evolutionary shapes are in conformity with the data of the literature. However, in number of African sets, the diagnosis is often presumptive and the weak proportion of germ identification [21] doesn't necessarily permit to pull applicable findings. But, in the sets with bacterial proof, the bacterial population is essentially composed by staphylococcus aureus, streptococcus and negative gram bacillus [19]-[23]. The African data differentiate themselves by a delay of diagnosis, the more numerous aftermaths, place of the sickle cell disease and HIV among the risk factors and by the weak number of iatrogenic causes in relation with the medical and surgical gestures [24] [25].

The first descriptions of joint attacks in relation with HIV infection were reported in the beginning of 1990 in sub-Saharan Africa [7] [26] [27]. Two nosological entities have been individualized: HIV associated arthritis [28]-[30] and spondyloarthropathies [26] [27] [31]. In the biggest sets described in Brazzaville, HIV associated arthritis didn't answer to the European's or Amor criterias of spondyloarthropathies [32].

Following the example of the first descriptions of rheumatoid arthritis [33]-[35] in sub-Saharan Africa, the diagnosed more recent cases and follow-up don't distinguish themselves to the descriptions of the literature.

As for the spondyloarthropathies, initially well-known rare because of the absence of HLA B27 antigen in the melanoderm group, prove to be frequent enough [11] [36]. They occupy the second place within the chronic inflammatory rheumatisms [10]. The ankylosing spondylitis is rare; in three decades, only four cases have been related in Brazzaville [37]. The rarity of HLA B27 is the main explication of it [38] [39]. In other respects, it is possible that independent protective factors of HLA B27, encourage a way of expression rather exsudative than enthesitic, not permitting to satisfy the criterias of classification of spondyloarthropathy [12] [29] [40].

Connective tissue diseases remain little frequent in African studies [14]. They are dominated by systemic lupus erythematous. The frequency and the severity of the lupus, well documented on Afro-Americans people, would be bound to genetic and socioeconomic factors [41]-[43]. The clinical presentation didn't differ between the black Caribbean's and the black Africans [44]. The weak number of cases described in sub-Saharan Africa seems to depend more on the weak capacities of biological diagnosis, than to a rarity of the disease [45].

\section{Conclusion}

To the term of three decades of rheumatologic practice in Brazzaville, it appears that frequency of indeterminate arthritis decreased from $21.82 \%$ to $5.47 \%$. The etiologies remain dominated and the order of frequency is gout, septic arthritis and HIV associated arthritis. Spondyloarthropathies and systemic erythematous lupus are increasingly reported. 


\section{References}

[1] Jeandel, P., Sanga, M., Fankam, H. and Kouda Zeh, K. (1988) Les arthropathies inflammatoires au Cameroun. Etude prospective de 122 observations. Médecine d'Afrique Noire, 35, 836-845.

[2] Mijiyawa, M., Djagnikpo, A.K., Agbanouvi, A.E., Koumouvi, K. and Agbetra, A. (1991) Maladies rhumatismales observées en consultation hospitalière à Lomé (Togo). Revue du Rhumatisme, 58, 349-354.

[3] Biléckot, R., Ntsiba, H., Mbongo, J.A., Masson, Ch. and Brégeon, Ch. (1992) Les affections rhumatismales observées en milieu hospitalier au Congo. Semaine des Hôpitaux Paris, 68, 282-285.

[4] Biléckot, R., Ntsiba, H., Mbongo, J.A., Signamong, E.V., Masson, Ch. and Bregeon, Ch. (1991) Aspects épidémiologiques et cliniques de la goutte en Afrique Equatoriale. A propos de 60 cas suivis dans le service de Rhumatologie du centre hospitalier et universitaire de Brazzaville. Revue du Rhumatisme, 58, 863-867.

[5] Adebajo, A. and Davis, P. (1994) Rheumatic Diseases in African Blacks. Seminars in Arthritis Rheumatism, 24, 139153. http://dx.doi.org/10.1016/S0049-0172(05)80007-1

[6] Mijiyawa, M., Djagnikpo, K., Dagbovie, K. and Agbetra, A. (1992) Gout in Togolese patients. Revue du Rhumatisme et Maladies Ostéoarticulaires, 59, 473-477.

[7] Biléckot, R., Masson, Ch., Ntsiba, H., Mbongo, J.A., et al. (1991) Etude prospective des manifestations rhumatologiques au cours de l'infection par le virus de l'immunodéficience humaine. A propos de 26 cas. Revue du Rhumatisme, 58, 163-168.

[8] Fautel, B. and Bourgeois, P. (2007) Le livre des critères, maladies systémiques. Pfizer, 66 p.

[9] Biléckot, R., Ntsiba, H., Okongo, D. and Ognami, J.B. (1994) Le diagnostic des arthrites en Afrique Noire. A propos de 473 cas au Congo. Revue du Rhumatisme, 61, 260-265.

[10] Oniankitan, O., Houzou, P., Komi, C., et al. (2013) Etiology of Arthritis in Lomé (Togo). Open Journal of Rheumatology and Auto immune Diseases, 3, 154-158. http://dx.doi.org/10.4236/ojra.2013.33023

[11] Mijiyawa, M., Ekoué, K., et al. (1994) Etiologies des polyarthrites chroniques à Lomé. Revue du Rhumatisme, 61, 29-35.

[12] Biléckot, R., Koubemba, G. and Nkoua, J.L. (1999) Etiologies des oligoarthrites en Afrique équatoriale. Etude rétrospective de 80 cas au Congo Brazzaville. Revue de Médecine Interne, 20, 408-411. http://dx.doi.org/10.1016/S0248-8663(99)83092-6

[13] Inaoui, R., Bertin, P., Preux, P.M. and Trèves, R. (2004) Devenir des mono arthrites indéterminées: Etude rétrospective de 46 cas. Revue du Rhumatisme, 71, 332-337. http://dx.doi.org/10.1016/S1169-8330(03)00337-5

[14] Nzenze, J.R., Belembaogo, E., Magne, A.S., et al. (2001) Panorama des arthropathies inflammatoires à Libreville. Analyse d'une série de 57 observations. Médecine d'Afrique Noire, 48, 399-402.

[15] Eti, E., Daboiko, J.C., Ouali, B., Akpangny, A., Ouattara, B., Gabla, A. and Kouakou N’zué, M. (2001) La goutte en milieu hospitalier ivoirien à propos de 33 cas. Afrique Biomédicale, 6, 31-35.

[16] Mody, G.M. and Naidoo, P.D. (1984) Gout in South African Blacks. Annals of Rheumatic Diseases, 43, 394-397. http://dx.doi.org/10.1136/ard.43.3.394

[17] So, A. and Busso, N. (2012) Actualité sur la goutte en 2012. Revue du Rhumatisme, 79, A22-A26. http://dx.doi.org/10.1016/s1169-8330(12)70057-1

[18] Jeandel, P. and Roux, H. (2002) Epidémiologie des affections rhumatologiques en Afrique sub-saharienne. Revue du Rhumatisme, 69, 764-776. http://dx.doi.org/10.1016/S1169-8330(02)00389-7

[19] Ntsiba, H., Makosso, E., Ngandeu-Singwé, M. and Yala, F. (2006) Les arthrites septiques en zone tropicale. A propos de 176 cas observés à Brazzaville. Mali Médical, 21, 49-54.

[20] Biléckot, R. and Missengué, A. (1998) Les arthrites septiques du genou observées en milieu hospitalier au Congo Brazzaville. A propos de 44 cas. Semaine des Hôpitaux Paris, 74, 966-969.

[21] Oniankitan, O., Bagayogo, Y., Fianyo, E., et al. (2011) Arthrites infectieuses en consultation rhumatologique à Lomé (Togo). Médecine Tropicale, 71, 61-62.

[22] Dubost, J.J., Soubier, M. and Sauvezie, B. (2000) Arthrite septique à pyogène de l'adulte. Revue du Rhumatisme, 67, 17-27. http://dx.doi.org/10.1016/S1169-8330(00)80043-5

[23] Dubost, J.J., Couderc, M., Tatar, Z., Tournadre, A., et al. (2014) Evolution sur 30 ans de la répartition des germes responsables d'arthrite septique sur articulation naïve. Etude monocentrique de 374 cas. Revue du Rhumatisme, 81, 495-497. http://dx.doi.org/10.1016/j.rhum.2014.04.003

[24] Biléckot, R., Miakoundoba, R.C. and Yala, F. (2006) Aspects bactériologiques et évolutifs des arthrites septiques à Brazzaville. Revue du Rhumatisme, 73, 966-967. http://dx.doi.org/10.1016/j.rhum.2005.11.019 
[25] Maugars, Y., Glémarec, J., Guillot, P., Berthelot, J.-M., Pot-Vaucel, M. and Le Goff, B. (2014) Infection iatrogène après geste interventionnel ostéoarticulaire. Incidence en Loire Atlantique en 2008. Revue du Rhumatisme, 81, 240245. http://dx.doi.org/10.1016/j.rhum.2013.09.004

[26] Stein, M. and Davis, P. (1989) HIV and Arthritis—Causal or Casual Acquaintances? Journal of Rheumatology, 16, 1287-1290.

[27] Davis, P., Stein, M., Latif, A. and Emmanuel, J. (1988) HIV and Polyarthritis. The Lancet, 331, 936. http://dx.doi.org/10.1016/S0140-6736(88)91738-2

[28] Biléckot, R., Mouaya, A. and Makuwa, M. (1998) Prévalence et forme clinique des arthrites au cours de l'infection à VIH dans un service de Rhumatologie du Congo-Brazzaville. Revue du Rhumatisme, 65, 605-611.

[29] Berman, A., Espinoza, L.R., Diaz, J.D., Aguilar, J.L., Rolando, T., Vasey, F.B., Germain, B.F. and Lockey, R.F. (1988) Rheumatic Manifestations of Human Immunodeficiency Virus Infection. American Journal of Medicine, 85, 59-64. http://dx.doi.org/10.1016/0002-9343(88)90503-7

[30] Biléckot, R. and Mouaya, A. (1998) Arthrite liée au VIH : une entité à part au cours de l'infection à VIH. Presse Médicale, 27, 806-807.

[31] Mijiyawa, M., Oniankitan, O. and Khan, M.A. (2000) Spondyloarthropathies in Sub-Saharan Africa. Current Opinion Rheumatology, 12, 281-286. http://dx.doi.org/10.1097/00002281-200007000-00008

[32] Ntsiba, H. and Lamini, N. (2004) Is Inflammatory Joint Disease in HIV-Infected Patients a Form of Spondylarthropathy? Joint Bone Spine, 71, 300-302. http://dx.doi.org/10.1016/S1297-319X(03)00118-0

[33] Biléckot, R. and Malonga, A.C. (1998) La polyarthrite rhumatoïde en milieu hospitalier au Congo-Brazzaville. A propos de trente-six cas. Revue du Rhumatisme, 65, 333-337.

[34] Mijiyawa, M. (1996) Polyarthrite rhumatoïde en Afrique noire. Revue de Médecine Interne, 17, 625-626. http://dx.doi.org/10.1016/0248-8663(96)87147-5

[35] Eti, E., Sylla, M., Daboiko, J.C., Ouali, B., Gabla, K.A. and Kouakou, N.M. (2000) Contribution à l'étude de la polyarthrite rhumatoïde en milieu ivoirien. A propos de 90 cas. Revue Internationale des Sciences Médicales, 2, 71-78.

[36] Biléckot, R. (2002) Diagnostic d’une arthrite en Afrique subsaharienne. Revue du Rhumatisme, 69, 791-796. http://dx.doi.org/10.1016/S1169-8330(02)00388-5

[37] Ntsiba, H. and Bazébissa, R. (2003) Quatre premiers cas de pelvispondylite rhumatismale. Bulletin de la Société de Pathologie Exotique, 96, 21-23.

[38] Saraux, A., Devauchelle, V., Jousse, S. and Le Goff, P. (2002) Spondylarthropathies Tropicales. Revue du Rhumatisme, 69, 809-813. http://dx.doi.org/10.1016/S1169-8330(02)00386-1

[39] Lopez-Larrea, C., Mijiyawa, M., Gonzalez, S., Fernandez-Morera, L., et al. (2002) Association of Ankylosing Spondylitis with HLA-B1403 in West African Population. Arthritis \& Rheumatology, 46, 2968-2971. http://dx.doi.org/10.1002/art.10584

[40] Brown, M.A., Jepson, A., Young, A., Whittle, H., Greenwood, B.M. and Wordsworth, B.P. (1997) Ankylosing Spondylitis in West African: Evidence for a Non-HLA-B27 Protective Effect. Annals of Rheumatic Diseases, 56, 68-70. http://dx.doi.org/10.1136/ard.56.1.68

[41] Janet, W., Maynard, H.F. and Petri, M. (2012) Low Socioeconomic Status Is Associated with Cardiovascular Risk Factors and Outcomes in Systemic Lupus Erythematosus. Journal of Rheumatology, 39, 777-783. http://dx.doi.org/10.3899/jrheum.110724

[42] Alarcon, G.S. (2011) Multiethnic Lupus Cohorts: What Have They Taught Us? Clinical Rheumatology, 7, 3-6. http://dx.doi.org/10.1016/j.reuma.2010.11.001

[43] Sanchez, E., Comeau, M.E., Freedman, B.I., Kelly, J.A., et al. (2011) Identification of Novel Genetic Susceptibility Loci in African American Lupus Patients Using a Candidate Gene Association Study. Arthritis \& Rheumatology, 63, 3493-501. http://dx.doi.org/10.1002/art.30563

[44] Eti, E., Hayem, G., Palazzo, E., de Brandt, M., Roux, S., Kahn, M.F. and Meyer, O. (1997) Le lupus systémique du sujet noir: comparaison chez les Africains (AF) et les Antillais (AN). Revue du Rhumatisme, 64, 800-801.

[45] Gilkeson, G.J., James, J.A., Kamen, D.L., et al. (2011) The United States to Africa Lupus Prevalence Gradient Revisited. Lupus, 20, 1095-1103. http://dx.doi.org/10.1177/0961203311404915 


\section{Submit or recommend next manuscript to SCIRP and we will provide best service for you:}

Accepting pre-submission inquiries through Email, Facebook, LinkedIn, Twitter, etc.

A wide selection of journals (inclusive of 9 subjects, more than 200 journals)

Providing 24-hour high-quality service

User-friendly online submission system

Fair and swift peer-review system

Efficient typesetting and proofreading procedure

Display of the result of downloads and visits, as well as the number of cited articles

Maximum dissemination of your research work

Submit your manuscript at: http://papersubmission.scirp.org/ 